\title{
Autoantibodies to the Low Density Lipoprotein Receptor in a Subject Affected by Severe Hypercholesterolemia
}

Alberto Corsini, Paola Roma, Domenico Sommariva," Remo Fumagalli, and Alberico L. Catapano

Institute of Pharmacology and Pharmacognosy, and *L. Sacco Hospital, Vialba, 20129 Milan, Italy

\begin{abstract}
We studied a 32-yr-old man with a benign paraproteinemia (IgA) affected by severe nonfamilial hypercholesterolemia. In vitro experiments demonstrated that lipoprotein-deficient serum (LPDS) from the patient inhibited the binding of low density lipoprotein (LDL) to human skin fibroblasts cultured in vitro (up to $70 \%$ ) whereas LPDS from controls had no effect. Removal of IgA from the patient's serum by immunoprecipitation with monospecific antisera abolished the inhibition of LDL binding. IgA isolated from the serum of the patient by affinity chromatography inhibited, in a dose-dependent manner, the binding of LDL to human skin fibroblasts in vitro, thus showing an IgA-mediated effect.
\end{abstract}

Ligand-blotting experiments demonstrated that the paraprotein directly interacts with the LDL receptor, thus inhibiting the binding of the lipoprotein. Treatment of the receptor protein with reducing agents blocked the interaction of the antibody with the LDL receptor. From these data we speculate that this autoantibody may be responsible for the severe nonfamilial hypercholesterolemia of the patient.

\section{Introduction}

Familial type IIa hypercholesterolemia is characterized by high levels of plasma cholesterol and premature coronary heart disease (1). Brown, Goldstein, and their co-workers in a series of elegant studies have elucidated the molecular basis of this syndrome, i.e., partial or almost complete lack of low density lipoprotein (LDL) receptors (2). The clinical counterpart of this biochemical defect is the presence of xanthomata, with typical distribution, and early coronary and aortic atherosclerosis which eventually leads to myocardial infarction.

Type Ila phenotype, however, may also result from a number of secondary causes. Hypothyroidism, for instance, induces hypercholesterolemia due to a down-regulation of LDL receptors, which can be reversed by specific treatment (3). The concept of autoimmune hyperlipoproteinemia was proposed by Beaumont and Beaumont (4), and since then patients with hyperlipemia have been found who have autoantibodies to circulating lipoproteins (5-7) as well as to enzymes related to lipoprotein catabolism (8). So far no patient has been reported to have autoantibodies to the LDL receptor. In this article we report on a subject affected by severe nonfamilial hypercholesterolemia whose serum contains a paraprotein that binds to the LDL receptor, thus inhibiting the ligand-receptor interaction.

Address reprint requests to Dr. Catapano, Institute of Pharmacology and Pharmacognosy, Via A de Sarto 21, 20129 Milan, Italy.

Received for publication 12 February 1986.

J. Clin. Invest.

(C) The American Society for Clinical Investigation, Inc.

$0021-9738 / 86 / 10 / 0940 / 07 \$ 1.00$

Volume 78, October 1986, 940-946
Case report. F.F., a 31-yr-old man, with a 10-yr history of hypercholesterolemia, was referred to us in January 1984 because of hypercholesterolemia (typically in the range of $600-900 \mathrm{mg}$ / dl). The patient had xanthoma at the elbows and thickening of achilles tendon was observed.

Known secondary causes of hypercholesterolemia were excluded. The familial anamnesis was negative and biochemical analysis indicated that his relatives were normocholesterolemic, suggesting a nonfamilial type IIa hypercholesterolemia. All relevant laboratory tests gave normal findings with the exception of immunoelectrophoresis of the serum proteins which showed the presence of a spike in the $\beta$-globulin zone. This peak was identified as an IgA (K-chain) by use of commercially available antibodies. IgA, IgG, and IgM plasma concentrations were within the normal range.

Bone marrow plasma cell count was normal $(<5 \%)$ as well as the radionuclide bone scan and the complete skeletal $\mathrm{x}$-ray analysis. Bence-Jones proteins were absent from the urine. These findings suggested the diagnosis of a monoclonal gammopathy of undetermined significance (9). The patient had angina and had had a myocardial infarction; he was also hypertensive (190/ $100 \mathrm{mmHg}$ ) for which he was treated with $\beta$-blockers. At age of 31 he suddenly died at home during the night. An autopsy was not performed.

\section{Methods}

Materials. Eagle's minimum essential medium (F-11), fetal calf serum, trypsin-EDTA $(\times 1)$, penicillin $(10,000 \mathrm{U} / \mathrm{ml})$, streptomycin $(10 \mathrm{mg} /$ $\mathrm{ml}$ ), tricine buffer (1 M, pH 7.4), Hepes (1 M, pH 7.4) and nonessential aminoacids $(\times 100)$, were purchased from Gibco (Grand Island, NY); disposable culture flasks and petri dishes were from Corning Glass Works (Corning, NY), filters from Millipore Corp. (Bedford, MA). Sodium ${ }^{125} \mathrm{I}$ iodide, carrier free in $0.1 \mathrm{~N} \mathrm{NaOH}$ was purchased from Amersham (Amersham, United Kingdom).

Sephadex G-25 and Sepharose 4B activated with cyanogen bromide $(\mathrm{CNBr})$ were obtained from Pharmacia (Uppsala, Sweden). Kits for enzymatic determination of plasma lipids were from Boehringer (Mannheim, Federal Republic of Germany). Monospecific antisera to IgA and immunodiffusion plates for IgA and IgG were gifts from Dr. Porta (Behring, Scoppito, Italy). Nitrocellulose membranes and all electrophoresis material and equipment were purchased from Bio-Rad Laboratories (Richmond, CA). All the reagents were analytical grade.

Plasma lipids and lipoproteins. Plasma was obtained in EDTA (0.1\%), cholesterol and triglycerides were determined by enzymatic procedures, apolipoproteins (apo) ${ }^{1}$ B and A-I were determined by radial immunodiffusion using antibodies raised in our laboratory in rabbits against purified apo B and apo A-I. Lipoproteins were fractionated by ultracentrifugation (10) using the following density cuts: very low density lipoprotein (VLDL)— $d<1.006 \mathrm{~g} / \mathrm{ml}, \mathrm{LDL}-d<1.019-1.063 \mathrm{~g} / \mathrm{ml}$, high density lipoprotein subfraction $3\left(\mathrm{HDL}_{3}\right)-d<1.125-1.21 \mathrm{~g} / \mathrm{ml}$. Fractions were spun for 16,24 , and $48 \mathrm{~h}$ respectively at $40,000 \mathrm{rpm}$ in a Beckman 50.2

1. Abbreviations used in this paper: apo, apolipoprotein; LPDS, lipoprotein-deficient serum. 
Ti Rotor (Beckman Instruments, Inc., Palo Alto, CA) at $12^{\circ} \mathrm{C}$. Lipoprotein triglyceride and cholesterol content was determined by enzymatic procedures. Lipoprotein-deficient serum (LPDS) was obtained as the serum fraction at $d<1.25 \mathrm{~g} / \mathrm{ml}$, by ultracentrifugation for $72 \mathrm{~h}$ at 40,000 rpm at $12^{\circ} \mathrm{C}$ in a Beckman $60 \mathrm{Ti}$ Rotor. Densities were adjusted by addition of solid $\mathrm{KBr}$ to the solutions.

All lipoproteins and the LPDS were dialyzed extensively against $\mathrm{NaCl}$ $0.15 \mathrm{M}$, EDTA $0.3 \mathrm{mM}, \mathrm{pH} 7.4$, and stored at $4^{\circ} \mathrm{C}$ after sterilization through a Millipore $0.45-\mu \mathrm{m}$ filter. The LPDS was stored at $-20^{\circ} \mathrm{C}$ and thawed just before use. $\mathrm{HDL}_{3}$ were further purified by heparin-Sepharose affinity chromatography to remove apo B- and apo E-containing lipoproteins (11).

Lipoproteins (LDL and HDL) were labeled with ${ }^{125}$ I according to Bilheimer et al. (12). Specific activities were $150-230 \mathrm{cpm} / \mathrm{ng}$ protein for LDL and $150 \mathrm{cpm} / \mathrm{ng}$ protein for $\mathrm{HDL}_{3}$. Free ${ }^{125}$ I was removed by column chromatography on a Sephadex G-25 column eluted with 0.15 $\mathrm{M} \mathrm{NaCl}, 0.3 \mathrm{mM}$ EDTA, $\mathrm{pH}$ 7.4. Fractions containing lipoproteins were collected and dialyzed against $0.15 \mathrm{M} \mathrm{NaCl}, 0.3 \mathrm{mM}$ EDTA, pH 7.4, overnight at $4^{\circ} \mathrm{C}$. Free iodine accounted for $<1 \%$ of total radioactivity. Lipid-associated radioactivity was always $<5 \%$ for LDL and $4 \%$ for HDL.

Immunoglobulin purification. The $d<1.25 \mathrm{~g} / \mathrm{ml}$ plasma fraction (LPDS) was used to study the effect of the patient's serum on lipoprotein metabolism. In some experiments IgA was immunoprecipitated using monospecific antisera at $4^{\circ} \mathrm{C}$ for $24 \mathrm{~h}$ and the supernatant was collected after centrifugation for $20 \mathrm{~min}$ at room temperature. The effectiveness of the precipitation was evaluated by radial immunodiffusion.

IgA was purified from control and the patient's LPDS by affinity chromatography using a rabbit anti-human IgA immunoglobulin coupled to a Sepharose $4 \mathrm{~B}$ activated with $\mathrm{CNBr}$ as recommended by the producers. The LPDS was loaded onto the column $(2.6 \times 4 \mathrm{~cm})$ and eluted with phosphate buffer, $\mathrm{pH} 7.4$ (10 vol of the column) followed by $10 \mathrm{vol}$ of glycine buffer (1 M, pH 2.5). Fractions of $0.5 \mathrm{ml}$ were collected and immediately adjusted to $\mathrm{pH}$ 7-7.4 with $1 \mathrm{M} \mathrm{NaOH}$. Protein content was measured as described by Lowry et al. (13). IgA was $>95 \%$ pure as determined by radial immunodiffusion using commercially available plates.

The interaction of LPDS (from control and patient F.F.'s serum) with LDL was also determined by affinity chromatography using a LDLSepharose column prepared using Sepharose $4 \mathrm{~B}$ activated with $\mathrm{CNBr}$ as described by the producers. The LPDS was loaded onto the column ( 2.6 $\times 3 \mathrm{~cm})$ and eluted first with phosphate-buffered saline (PBS) (10 vol of the column) and then with glycine buffer ( $1 \mathrm{M}, \mathrm{pH} 2.5)$. Fractions of $0.25 \mathrm{ml}$ were collected and immediately adjusted to $\mathrm{pH}$ 7-7.4 with 0.1 $\mathrm{M} \mathrm{NaOH}$ and their protein content was determined according to Lowry et al. (13). The column was used within $2 \mathrm{~d}$ after its preparation.

Cell culture. Human skin fibroblasts were grown from explants of skin biopsies obtained from the patient and from normolipidemic clinically healthy individuals. Cells were grown in monolayers and maintained in $75-\mathrm{cm}^{2}$ plastic flasks at $37^{\circ} \mathrm{C}$ in a humidified atmosphere of $95 \%$ air, $5 \% \mathrm{CO}_{2}$ in $\mathrm{F}-11$ medium supplemented with $10 \%$ fetal calf serum, nonessential aminoacid solution ( $1 \%$, vol/vol), penicillin $(100 \mathrm{U} / \mathrm{ml})$, streptomycin $(100 \mu \mathrm{g} / \mathrm{ml})$, tricine buffer $(20 \mathrm{mM}, \mathrm{pH} 7.4)$, and $\mathrm{NaCO}_{3}$ $(24 \mathrm{mM})$. For all experiments, cells from the stock flask were dissociated with $0.05 \%$ trypsin- $0.02 \%$ EDTA at confluency ( $5-15$ passages), seeded in 60 -mm plastic petri dishes $\left(2.5 \times 10^{5}\right.$ cells), and used just before reaching confluency, usually $6 \mathrm{~d}$ after plating. The medium was changed every 2-3 d. Cell viability, assessed by Trypan blue exclusion, was always $>95 \%$.

The cell surface binding of ${ }^{125} \mathrm{I}-\mathrm{LDL}$ was determined as heparinreleasable radioactivity (14). Monolayers were then digested in $0.1 \mathrm{~N}$ $\mathrm{NaOH}$ at room temperature overnight; one aliquot was counted for residual cell radioactivity as a measure of LDL internalization and another aliquot used for cell protein assay (13). For total uptake (binding and internalization) of LDL, cell monolayers were directly digested in $0.1 \mathrm{~N}$ $\mathrm{NaOH}$ after standard washing procedures. The specific LDL binding, internalization, and total uptake were computed by subtracting values observed in the presence of 50 -fold excess of unlabeled LDL from those obtained in their absence. LDL degradation was measured from the accumulation of noniodide trichloroacetic acid-soluble ${ }^{125} \mathrm{I}$ in the incubation medium in excess of that occurring in the absence of cells (14). Each experimental point represents the average value of triplicate incubations. In all experiments cells were preincubated for $24 \mathrm{~h}$ at $37^{\circ} \mathrm{C}$ in a medium containing 5\% human LPDS to induce LDL receptors.

When appropriate the preincubation period was followed by incubation for $2 \mathrm{~h}$ at $37^{\circ} \mathrm{C}$ in a medium containing increasing amounts of LPDS or IgA fraction obtained from control and from the patient serum. Cells were then washed three times with PBS, ${ }^{125}$ I-LDL were added in a fresh medium containing $5 \%$ of normal LPDS, and the incubation was carried out either at $37^{\circ} \mathrm{C}$ or $4^{\circ} \mathrm{C}$ for $5 \mathrm{~h}$ or $2 \mathrm{~h}$, respectively. Binding, internalization, and degradation of labeled LDL were determined as described above. For experiments performed at $4^{\circ} \mathrm{C}$, cells were placed for $30 \mathrm{~min}$ at $4^{\circ} \mathrm{C}$; the medium was then removed and replaced with a chilled F-11 medium without bicarbonate and tricine supplemented with $10 \mathrm{mM}$ Hepes (pH 7.4), 5\% LPDS, penicillin, streptomycin, $1 \%$ nonessential aminoacids, and the indicated concentration of ${ }^{125}$ I-LDL.

For competition experiments, cells were incubated with a fixed concentration of ${ }^{125} \mathrm{I}-\mathrm{LDL},(5 \mu \mathrm{g}$ of LDL protein) in the presence of increasing concentrations of unlabeled LDL from control and patient serum.

To show specificity of the effect on the binding of LDL to their cellular receptor, we studied the binding of ${ }^{125} \mathrm{I}-\mathrm{HDL}_{3}$ to human skin fibroblasts. The experiments were performed as described by Biesborek et al. (15) after incubation of the cells in an albumin containing medium for $24 \mathrm{~h}$. The binding of HDL was then evaluated as cell-associated radioactivity because it has been shown that under these conditions no appreciable internalization and degradation of HDL occur by human skin fibroblasts (15).

Ligand-blotting experiments. Ligand-blotting analysis was performed as described by Daniel et al. (16) using bovine adrenals as a source of membranes rich in the LDL receptor (17). Membranes were prepared as described (17) at $100,000 \mathrm{~g}$ and stored at $-80^{\circ} \mathrm{C}$ as a pellet until use. On the day of the experiment the pellet was thawed and solubilized in $1 \%$ Triton X-100 (final concentration). The soluble fraction was separated from the particulate material by ultracentrifugation at $100,000 \mathrm{~g}$ for $1 \mathrm{~h}$ at $4^{\circ} \mathrm{C}$ and applied to a $5 \%$ acrylamide gel containing $0.1 \%$ sodium dodecyl sulphate. Electrophoresis was run at $15 \mathrm{~mA}$ per plate for $6 \mathrm{~h}$. The separated proteins were then blotted to a nitrocellulose membrane as described by Burnette (18) at $4^{\circ} \mathrm{C}$ at $250 \mathrm{~mA}$ for $6 \mathrm{~h}$. Efficiency of blotting was determined by staining of the gels; $>85 \%$ of the protein was blotted to the nitrocellulose. The cellulose was then incubated with buffer A containing 3\% albumin to quench the nonspecific binding sites. ${ }^{125} \mathrm{I}$ $\mathrm{LDL}$ at a final concentration of $10 \mu \mathrm{g}$ protein $/ \mathrm{ml}$ were then added to buffer $\mathrm{A}$ and incubated at $27^{\circ} \mathrm{C}$ for $2-3 \mathrm{~h}$. The incubation medium was removed and the nitrocellulose sheet was washed at $4^{\circ} \mathrm{C}$ with the same buffer containing no LDL (three washes, $30 \mathrm{~min}$ each).

In some experiments, after the incubation with albumin, the nitro-

Table I. Plasma Lipids and Cholesterol Distribution among Lipoproteins in the Patient

\begin{tabular}{lcc}
\hline & Patient & Controls \\
\hline & $m g / d l$ & $m g / d l$ \\
Plasma cholesterol $^{*}$ & $600-900$ & $190 \pm 18$ \\
Plasma triglyceride* & $153-212$ & $94 \pm 29$ \\
VLDL cholesterol $\ddagger$ & 40 & $17 \pm 11$ \\
LDL cholesterol $\ddagger$ & 538 & $123 \pm 14$ \\
HDL cholesterol $\ddagger$ & 40 & $48 \pm 6.6$ \\
Apo B $\ddagger$ & 276 & $87 \pm 12$ \\
Apo A-I $\ddagger$ & 121 & $139 \pm 17$ \\
\hline
\end{tabular}

* Range in four separate determinations.

$¥$ Plasma cholesterol was $640 \mathrm{mg} / \mathrm{dl}$.

$\S$ Values are the mean \pm SD of 20 normal subjects matched for sex and age. 


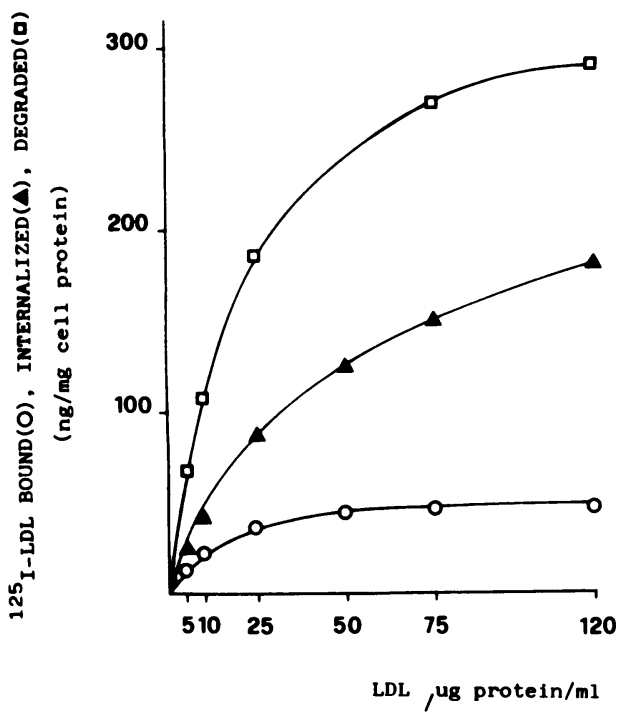

cellulose was incubated for $2 \mathrm{~h}$ with LPDS (control or patient F.F.); final concentration was $120 \mu \mathrm{g}$ protein $/ \mathrm{ml}$. The experiment was then performed as outlined for the LDL.

To study the direct binding of patient IgA to the LDL receptor, the immunoglobulin fraction was iodinated by the iodogen procedure (19) to a specific activity of $1,500-1,900 \mathrm{cpm} / \mathrm{ng}$. The experiments of ligand blotting were performed as for the LDL. The dried nitrocellulose sheets were then processed for autoradiography at $-80^{\circ} \mathrm{C}$ using an intensifier screen.

\section{Results}

Table I shows the plasma lipid levels and the cholesterol distribution among lipoproteins in the patient. The phenotype was

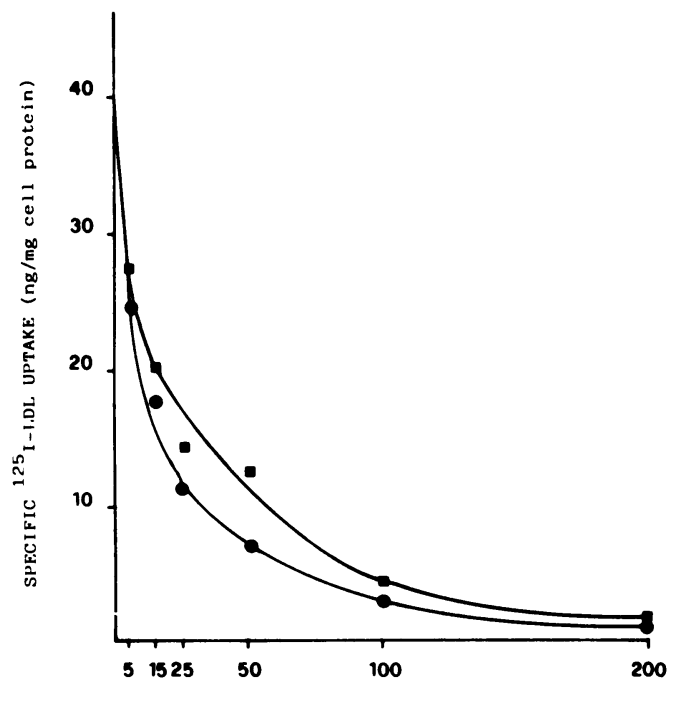

LDL, ug protein/ml

Figure 2. Effect of control ( $\square$ ) and patient F.F.'s ( $\bullet$ LDL on the uptake of ${ }^{125}$ I-LDL by cultured human skin fibroblasts. ${ }^{125} \mathrm{I}-\mathrm{LDL}$

$(5 \mu \mathrm{g} / \mathrm{ml})$ were incubated for $5 \mathrm{~h}$ at $37^{\circ} \mathrm{C}$ with the cells in presence of the indicated amount of unlabeled LDL from a normolipemic subject and from patient F.F. The nonspecific uptake was the LDL uptake in the presence of $500 \mu \mathrm{g} / \mathrm{ml}$ of control LDL. Each point is the mean of triplicate determinations that did not differ by $>10 \%$.
Figure 1. Specific binding (o), internalization ( $\triangle$ ), and degradation ( $\square$ ) of control ${ }^{125}$ I-LDL in vitro by cultured fibroblast from a normolipemic subject $(l e f t)$ and patient F.F. (right). Increasing concentrations of ${ }^{125} \mathrm{I}-\mathrm{LDL}$ were incubated with the cells for $5 \mathrm{~h}$. The binding, internalization, and degradation were determined as described in Methods. Each point is the mean of triplicate determinations that did not differ by $>10 \%$.

The nonspecific binding, internalization, and degradation were the values obtained in the presence of $500 \mu \mathrm{g} / \mathrm{ml}$ of unlabeled LDL.
IIa. Family studies showed, however, that both parents were normocholesterolemic (father $210 \mathrm{mg} / \mathrm{dl}$; mother $190 \mathrm{mg} / \mathrm{dl}$ ), thus ruling out the possibility that we were dealing with a subject affected by familial hypercholesterolemia. In fact, studies on cultured skin fibroblasts obtained from patient F.F. showed that the binding, internalization, and degradation of LDL was normal (Fig. 1). The LDL from the patient efficiently interacted with the LDL receptor as shown in Fig. 2. The patient LDL were as effective as control LDL in competing for ${ }^{125}$ I-LDL uptake, as well as degradation (data not shown).

Fig. 3 shows the effect of control and patient F.F.'s LPDS on the ${ }^{125} \mathrm{I}-\mathrm{LDL}$ degradation by human skin fibroblasts at $37^{\circ} \mathrm{C}$.

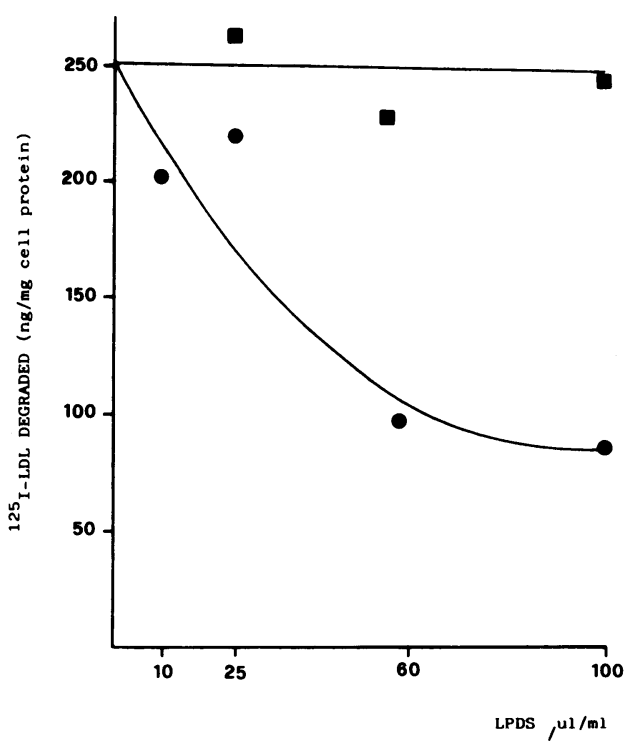

Figure 3. Effect of control ( $\bullet$ ) and patient F.F.'s (๑) LPDS on the degradation of ${ }^{125}$ I-LDL by cultured skin fibroblasts. Cells were preincubated with the indicated amount of control LPDS for $2 \mathrm{~h}$ at $37^{\circ} \mathrm{C}$. Protein concentration of control and patient F.F.'s LPDS was 20 $\mathrm{mg} / \mathrm{ml}$. The monolayer was washed thrice with PBS and then incubated for $6 \mathrm{~h}$ with ${ }^{125} \mathrm{I}-\mathrm{LDL}(10 \mu \mathrm{g} / \mathrm{ml})$ at $37^{\circ} \mathrm{C}$. LDL degradation was determined as described in Methods. Each point is the mean of triplicate determinations that did not differ by $>10 \%$. 


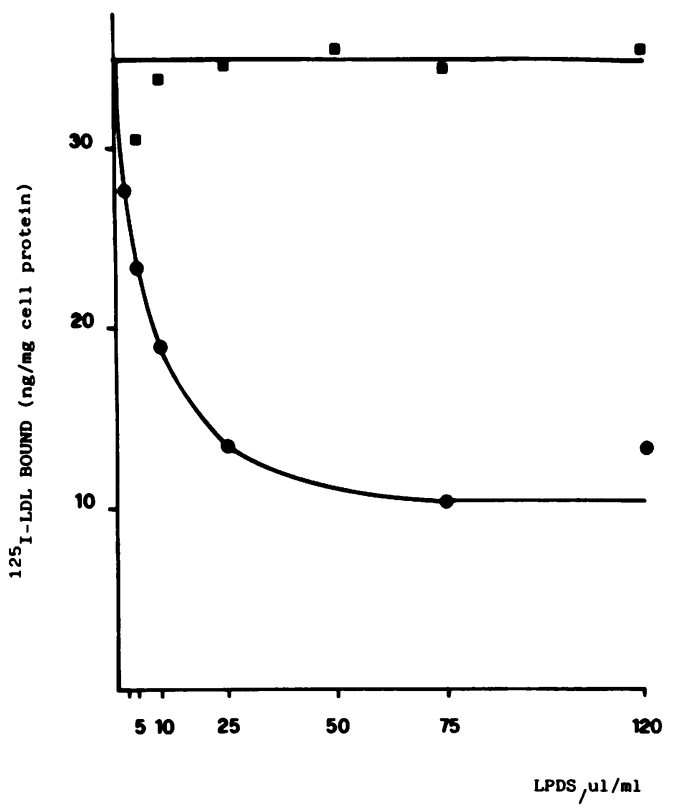

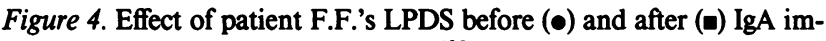
munoprecipitation on the binding of ${ }^{125} \mathrm{I}-\mathrm{LDL}$. Cells were preincubated with LPDS for $2 \mathrm{~h}$ at $37^{\circ} \mathrm{C}$ at the concentrations indicated in the figure. Protein concentration of the LPDS was $20 \mathrm{mg} / \mathrm{ml}$. The cells were then washed thrice with PBS and the binding of ${ }^{125} \mathrm{I}-\mathrm{LDL}$ assayed at $4^{\circ} \mathrm{C}$ as described in Methods. The nonspecific binding was the ${ }^{125} \mathrm{I}-\mathrm{LDL}$ bound in the presence of $500 \mu \mathrm{g} / \mathrm{ml}$ of unlabeled LDL. Each point is the mean of triplicate determinations differing $<10 \%$.

Similar results were obtained for the binding at $4^{\circ} \mathrm{C}$ (data not shown). LPDS from the patient clearly inhibited this process while control LPDS did not.

Immunoprecipitation of $\operatorname{IgA}$ from the LPDS resulted in a loss of the inhibitory activity (Fig. 4), suggesting that the IgA was responsible for the LPDS effect. To directly address this question, IgA were purified to homogeneity by affinity chromatography. This immunoglobulin was as effective as whole LPDS in inhibiting ${ }^{125} \mathrm{I}-\mathrm{LDL}$ uptake and degradation whereas control IgA had no effect (Fig. 5). It was therefore demonstrated that in our patient the IgA fraction was responsible for the effects of LPDS upon the receptor-mediated catabolism of LDL.
Although the tissue culture experiments were performed to avoid any direct interaction in the medium between LDL and LPDS or IgA, we also performed affinity-chromatography studies to show that no interaction between LDL and the patient LPDS components occurred. Indeed, these experiments showed that none of the proteins present in the patient and control LPDS interacted with LDL under the conditions used (Fig. 6) whereas a rabbit antiserum to apo $B$ contained a fraction that interacted with LDL. To verify the specificity of the LPDS from the patient in inhibiting the binding of LDL, we studied its ability to interfere with the binding of apo E-free $\mathrm{HDL}_{3}$ to human skin fibroblasts. The results in Table II show that neither control nor patient F.F.'s LPDS affected the ${ }^{125} \mathrm{I}-\mathrm{HDL}$ binding.

Using the ligand-blotting technique, we then addressed the question as to whether the $\operatorname{IgA}$ from our patient interacted directly with the LDL receptor. The patient's LPDS effectively inhibited the binding of LDL to the receptor in this assay as shown in Fig. 7 (lanes $E$ and $F$ ), thus demonstrating a direct effect on the receptor protein. Fig. 8 shows that ${ }^{125}$ I-labeled IgA purified from patient F.F.'s serum directly interacted with a protein of approximately $160,000 \mathrm{~mol}$ wt (lanes $A-C$ ) with the same mobility of the LDL receptor (lanes $E$ and $F$ ). Treatment of the membranes with reducing agents abolished the interaction of patient F.F.'s IgA with the LDL receptor (lane $D$ ).

\section{Discussion}

Hypercholesterolemia (type IIa) is a risk factor for coronary heart disease (1). Genetic forms of this disease relate to the deficiency (partial or total) of LDL receptors; hypercholesterolemic subjects exist, however, that are nonfamilial and therefore no loss of receptor activity occurs (1).

Autoantibodies to lipoprotein receptors have not been previously recognized as "secondary" causes of hypercholesterolemia. However, autoantibodies to other receptors (insulin, acetylcholine, and thyrotropin) have been described (20-22), which lead to severe forms of diabetes, myasthenia gravis, and Graves' syndrome. Autoantibodies to lipoprotein components as well as to lipolytic enzymes have also been reported (4-8), and these conditions are related to hyperlipemia with increased plasma concentrations of triglycerides and cholesterol.

We report here on a patient whose LPDS contains an antibody-like protein that inhibits the receptor-mediated binding
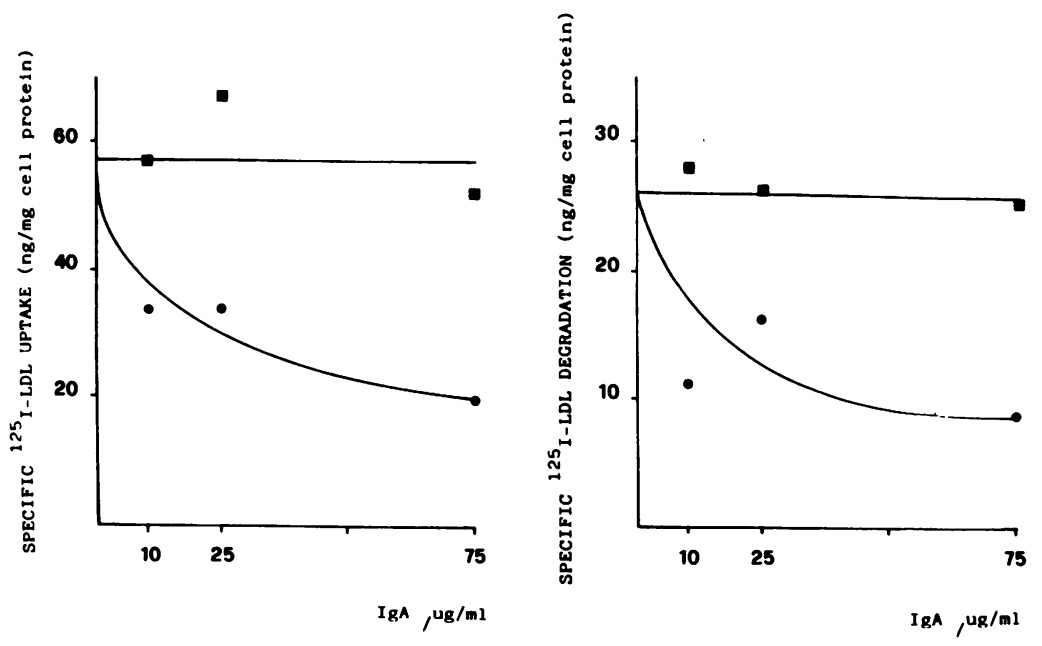

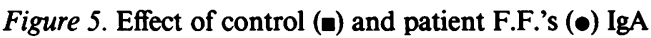
on the uptake and degradation of ${ }^{125} \mathrm{I}$-LDL by cultured skin fibroblasts. Cells were preincubated with IgA as described in the legends to Figs. 3 and 4 and then incubated for $5 \mathrm{~h}$ at $37^{\circ} \mathrm{C}$ in presence of $10 \mu \mathrm{g} / \mathrm{ml}$ of ${ }^{125} \mathrm{I}$ LDL. The nonspecific uptake was the uptake in the presence of $500 \mu \mathrm{g} / \mathrm{ml}$ unlabeled LDL. Each point is the mean of triplicate determinations that did not differ by IgA, $\mathrm{ug} / \mathrm{ml}>10 \%$. 


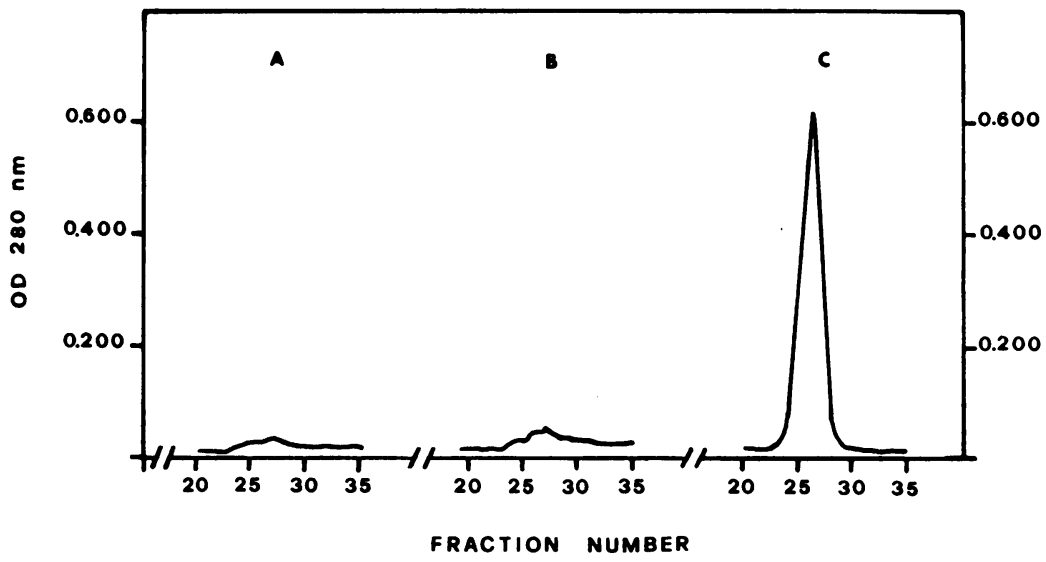

Figure 6. Elution profile of a LDL-Sepharose column. Patient F.F. LPDS $(A)$, control LPDS $(B)$, and a rabbit polyclonal anti-human apo B serum $(C)$ were applied to the column. Only the fractions eluted with $1 \mathrm{M}$ glycine, $\mathrm{pH} 2.5$, are presented. and catabolism of LDL by human skin fibroblasts in vitro. The experiments performed after immunoprecipitation of IgA strongly suggest that this factor is an antibody (see Fig. 4), and the data obtained using purified IgA indeed show that the activity is completely attributable to this globulin fraction (Fig. 5).

It is known that monoclonal antibodies to Apo B may inhibit LDL catabolism $(23,24)$. The lipoprotein profile of our patient, however, differs from that of subjects whose serum contains autoantibodies against LDL. These patients have, in fact, also increased plasma triglyceride levels and most of the antibody can be found at the $d<1.21 \mathrm{~g} / \mathrm{ml}$ top $(5,8)$ associated with lipoproteins. Our patient was normotriglyceridemic, his LDL were normal both in chemical composition and ability to interact with cellular receptors, and the inhibiting activity was not associated with lipoproteins. Along this line we have also shown that this antibody does not bind to LDL (see Fig. 6); these data, however, must be regarded with caution, for under the experimental conditions used, an antibody may fail to interact with LDL or may not be released from the column. Nevertheless, these data further support the tissue culture experiments in vitro which were designed to avoid any direct interaction between LPDS or IgA and LDL in the medium.

The antibody might therefore act by directly binding the receptor or interacting with the cell membrane near the LDL receptor producing steric hindrance of the LDL-receptor interaction. Alternatively, the antibody might interact with a mem-

Table II. Effect of LPDS on the Binding of Apo E-free $\mathrm{HDL}_{3}$ to Fibroblasts*

\begin{tabular}{lll}
\hline & \multicolumn{2}{l}{${ }^{125} \mathrm{I}_{-} \mathrm{HDL}_{3}$ bound } \\
\cline { 2 - 3 } LPDS & F.F. & Control \\
\hline$\mu l / m l$ & $n g$ & $n g$ \\
- & 69.9 & 69.9 \\
20 & 63.2 & 70.1 \\
50 & 69.0 & 60.2 \\
150 & 61.4 & 72.9
\end{tabular}

* Data are expressed as nanograms of ${ }^{125} \mathrm{I}-\mathrm{HDL}$ protein bound per milligram of cell protein. Cells were preincubated with a medium containing albumin for $24 \mathrm{~h}$ and the binding determined at $37^{\circ} \mathrm{C}$ as described in Methods. The data are means of triplicate determinations that did not differ by $>10 \%$. brane component distant from the receptor, modulating the LDL-receptor interaction. To study the specificity of this antibody, we investigated whether it could also affect the binding of $\mathrm{HDL}_{3}$ to human skin fibroblasts (see Table II). Binding sites for HDL are present on a number of tissues and are distinct in terms of specificity and regulation from the LDL receptor. (15, $25,26)$. No interference with the binding of HDL was found suggesting that the effect of the antibody is specific, at least among the lipoproteins, for the LDL receptor. Finally, the ligand-blotting experiments demonstrate that IgA from the patient interact in vitro with the LDL receptor and that treatment of the membrane proteins with reducing agents destroys the epitope recognized by the antibody, suggesting that the area of the receptor involved in the LDL binding contains the epitope(s) recognized by the antibody. A loss of the receptor secondary structure abolishes the binding of LDL as well as of the antibody. Interestingly, the epitope for a mouse monoclonal antibody was also not retained after exposure of the LDL receptor to reducing agents (16).

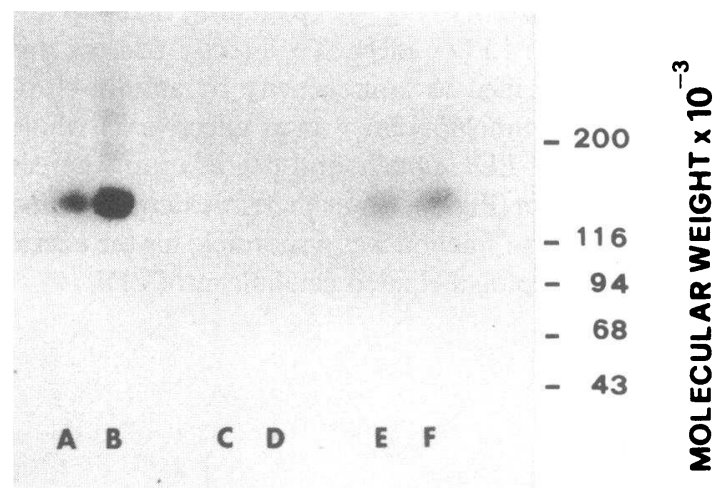

Figure 7. Effect of patient F.F.'s LPDS on the binding of ${ }^{125}$ I-LDL to the LDL receptor from bovine adrenal cortexes. For the ligand-blotting assay, membranes were solubilized with Triton X-100 (1\% vol/ vol) and run on a $5 \%$ sodium dodecyl sulfate-acrylamide gel, blotted to a nitrocellulose filter. $25 \mu \mathrm{g}$ (lanes $A, C$, and $E$ ) or $50 \mu \mathrm{g}$ (lanes $B$, $D$, and $F$ ) of membrane protein were applied to the gels. The lanes were cut and incubated at $27^{\circ} \mathrm{C}$ for $2 \mathrm{~h}$ with control LPDS (120 $\mu \mathrm{g} / \mathrm{ml}$, lanes $A$ and $B)$ or patient F.F.'s LPDS $(120 \mu \mathrm{g} / \mathrm{ml}$, lanes $E$ and $F$ ). The sheets were washed and incubated at $27^{\circ} \mathrm{C}$ for $2 \mathrm{~h}$ with ${ }^{125} \mathrm{I}$ LDL $(10 \mu \mathrm{g} / \mathrm{ml})$ without unlabeled LDL (lanes $A, B, E$, and $F)$ or with $0.5 \mathrm{mg} / \mathrm{ml}$ unlabeled LDL (lanes $C$ and $D$ ). The high molecular weight components in lane $B$ may represent aggregated receptor protein. 


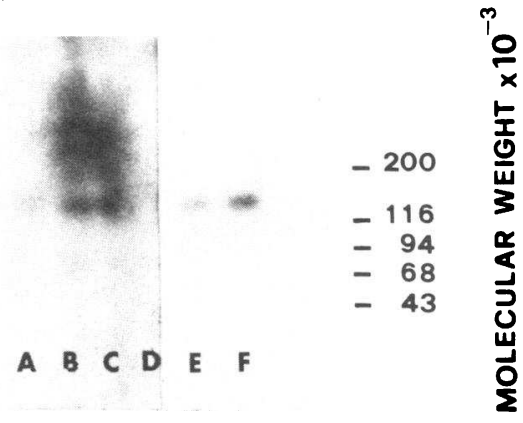

Figure 8. Binding of ${ }^{125}$ I-labeled IgA isolated from patient F.F.'s LPDS to the LDL receptor. IgA were labeled with ${ }^{125}$ I as described in Methods. $5,10,15$, and $10 \mu \mathrm{g}$ of membrane protein (lanes $A-D$ ) were applied to the sodium dodecyl sulfate acrylamide gels and were blotted to nitrocellulose. The binding was performed in PBS containing 2\% bovine serum albumin for $2 \mathrm{~h}$ at $27^{\circ} \mathrm{C}$. The sample in lane $D$ was pretreated with $5 \% \beta$-mercaptoethanol. For comparative purposes the binding of ${ }^{125} \mathrm{I}-\mathrm{LDL}$ is shown (lanes $E$ and $F, 10$ and $15 \mu \mathrm{g}$ of membrane protein applied). The area of higher moleculer weight in lanes $A, B$, and $C$ may represent aggregated receptor protein.

The degree of hypercholesterolemia in our patient is comparable to that of homozygotes for familial hypercholesterolemia, although at the most the antibody reduces LDL binding to the receptor by $70 \%$. Patients receptor-defective also have severe hypercholesterolemia even though $15-20 \%$ of the receptor activity is present (1).

The causal relation between antibodies and hypercholesterolemia in our patient, although likely, is not demonstrated. Beisiegel et al. (27) and Kita et al. (28) reported that antibodies to the LDL receptor interfere with LDL catabolism in vitro as well as in vivo. In this respect our patient will be very similar to patients with severe insulin resistance, Graves' disease, or myasthenia gravis who have autoantibodies to the insulin, acetylcholine, and thyrotropin receptors, respectively (20-22). These antibodies have a number of physiologic effects and some also mimic the effect of the physiological ligand (29). The question as to whether binding of the autoantibody to the LDL receptor in our patient leads to the receptor internalization and downregulation as it occurs for $\operatorname{LDL}(1,2)$ remains to be addressed.

Finally, this autoantibody recognized also the LDL receptor present on bovine adrenal cortexes. A mouse monoclonal antibody against the bovine receptor cross-reacts with the human, bovine, and dog LDL receptor (27) but does not recognize the rabbit receptor. We are currently addressing the question as to whether patient F.F.'s IgA has a broad interspecies specificity.

In summary, we have described in the plasma of a hypercholesterolemic patient the presence of autoantibodies to the LDL receptor that inhibit the in vitro catabolism of LDL. The clinical history of the patient is similar to that of the homozygous and heterozygous forms of hypercholesterolemia. Screening among the nonfamilial forms of moderate and severe hypercholesterolemia may result in the discovery of other patients.

\section{Acknowledgments}

The authors wish to thank Mrs. Silvana Magnani for typing the manuscript.

This work was supported in part by a grant to Dr. Catapano from P. F. Malattie Degenerative No. 850049356 and from the Ministero Pubblica Istruzione.

\section{References}

1. Goldstein, J. L., and M. S. Brown. 1983. Familial hypercholesterolemia. In The Metabolic Basis of Inherited Disease. J. B. Stanbury, G. B. Wyngaarden, D. Fredrickson, J. L. Goldstein, and M. S. Brown, editors. McGraw-Hill Book Co., New York. 672-712.

2. Goldstein, J. L., and M. S. Brown. 1984. Progress in understanding the LDL receptor and HMG CoA reductase, two membrane proteins that regulate the plasma cholesterol. J. Lipid Res. 25:1451-1476.

3. Thompson, G. R., A. K. Soutar, F. A. Spengel, A. Jadhav, S. J. Gavignan, and N. B. Myant. 1981. Defects of receptor-mediated low density lipoprotein catabolism in homozygous familial hypercholesterolemia and hypothyroidism in vivo. Proc. Natl. Acad. Sci. USA. 78: 2591-2595.

4. Beaumont, J. L., and V. Beaumont. 1977. Autoimmune hyperlipidemia. Atherosclerosis. 26:405-418.

5. Lewis, L. A., V. G. De Wolfe, A. Butkus, and I. H. Page. 1975. Autoimmune hyperlipidemia in a patient. Am. J. Med. 59:208-218.

6. Riesen, W., and G. Noseda. 1975. Antibodies against lipoproteins in man, occurence and biological significance. Klin. Wochenschr. 53: 353-361.

7. Kilgore, L., B. W. Patterson, D. M. Parenti, and W. R. Fisher. 1985. Immunocomplex hyperlipidemia induced by an apolipoproteinreactive immunoglobulin A paraprotein from a patient with multiple myeloma. J. Clin. Invest. 76:225-232.

8. Beaumont, J. L., M. Berard, A. Antonucci, B. Deplanque, and R. Vranckx. 1977. Inhibition of lipoprotein lipase activity by a monoclonal immunoglobulin in autoimmune hyperlipidemia. Atherosclerosis. 26: 67-77.

9. Selman, S. E. 1982. Monoclonal gammopathies of undetermined significance. In Textbook of Medicine. J. B. Wyngaarden and L. M. Smith, editors. W. B. Saunders, Philadelphia. 973-981.

10. Havel, R. J., H. A. Eder, and J. H. Bragdon. 1955. The distribution and chemical composition of ultracentrifugally separated lipoproteins in human serum. J. Clin. Invest. 34:1345-1354.

11. Weisgraber, K. H., and R. W. Mahley. 1980. Subfractionation of human high density lipoproteins by heparin-Sepharose affinity chromatography. J. Lipid Res. 21:316-325.

12. Bilheimer, D. W., S. Eisemberg, and R. I. Levy. 1972. The metabolism of very low density lipoprotein proteins. I. Preliminary in vitro and in vivo observations. Biochim. Biophys. Acta. 260:212-221.

13. Lowry, O. H., N. J. Rosenbrough, A. L. Farr, and R. J. Randall. 1951. Protein measurement with the Folin phenol reagent. J. Biol. Chem. 193:265-275.

14. Goldstein, J. L., S. K. Basu, and M. S. Brown. 1983. Receptor mediated endocytosis of low density lipoprotein in cultured cells. Methods Enzymol. 98:241-260.

15. Biesborek, R. J., J. F. Oram, J. J. Albers, and E. L. Bierman. 1983. Specific high-affinity binding of high density lipoproteins to cultured human skin fibroblasts and arterial smooth muscle cells. J. Clin. Invest. 71:525-539.

16. Daniel, T. O., W. J. Schneider, J. L. Goldstein, and M. S. Brown. 1983. Visualization of lipoprotein receptors by ligand blotting. J. Biol. Chem. 284:4606-4611.

17. Schneider, W. J., J. L. Goldstein, and M. S. Brown. 1980. Partial purification and characterization of the low density lipoprotein receptor from bovine adrenal cortex. J. Biol. Chem. 255:11442-11447.

18. Burnette, W. N. 1981. "Western blotting": electrophoretic transfer of proteins from sodium sulphate polyacrylamide gels to unmodified nitrocellulose and radioagraphic detection with antibody and radioiodinated protein A. Anal. Biochem. 112:195-203.

19. Fraker, P. J., and J. C. Speck, Jr. 1980. Protein and cell membrane iodinations with a sparingly soluble chloroamide 1,3,4,6-tetrachloro 3a,6a diphenylglycoluril. Biochem. Biophys. Res. Commun. 80:849-857.

20. Flier, J. S., R. Kahn, J. Roth, and R. S. Bar. 1975. Antibodies 
that impair insulin receptor binding in an unusual diabetic syndrome with severe insulin resistance. Science (Wash. DC). 190:63-65.

21. Smith, B. R., and R. Hall. 1979. Thyroid-stimulating immunoglobulins in Graves' disease. Lancet. ii:427-431.

22. Almon, R. R., C. G. Amurew, and S. H. Appel. 1974. Serum globulin in myasthenia gravis: inhibition of $\alpha$-bungarotoxin binding to acetylcholine receptors. Science (Wash. DC). 186:55-57.

23. Milne, R. W., R. Theolis, R. B. Verdery, and Y. L. Marcel. 1983. Characterization of monoclonal antibodies against human low density lipoproteins. Arteriosclerosis. 3:23-30.

24. Tikkanen, M. J., R. Dragar, B. Pleger, B. Goneh, J. M. Davie, and G. Schonfeld. 1982. Antigenic mapping of human low density lipoprotein with monoclonal antibodies. J. Lipid Res. 23:1032-1038.

25. Chacko, G. K. 1984. Characterization of high density lipoprotein binding sites in rat liver and testes membrane. Biochim. Biophys. Acta. 795:417-426.
26. Trezzi, E., G. Maione, and A. L. Catapano. 1984. Binding of high density lipoprotein ${ }_{3}$ to human liver membranes. IRCS (Int. Res. Commun. Syst.) Med. Sci. 12:472-473.

27. Beisiegel, U., W. J. Schneider, J. L. Goldstein, R. G. Anderson, and M. S. Brown. 1981. Monoclonal antibodies to the low density lipoprotein receptor as probes for study of receptor mediated endocytosis and the genetics of familial hypercholesterolemia. J. Biol. Chem. 256: 11923-11931.

28. Kita, T., U. Beisiegel, J. L. Goldstein, W. J. Schneider, and M. S. Brown. 1981. Antibody against low density lipoprotein receptor blocks uptake of low density lipoproteins (but not high density lipoproteins) by the adrenal gland of the mouse in vivo. J. Biol. Chem. 256: 4701-4703.

29. Taylor, S. I., G. Grumberger, B. Marcus-Samuel, L. Underhill, R. F. Dons, J. Ryan, R. F. Roddam, C. E. Rupe, and P. Gorden. 1982. Hypoglycemia associated with antibodies to the insulin receptor. $N$. Engl. J. Med. 307:1422-1426. 